\title{
Cisgenesis Does Not Solve the Late Blight Problem of Organic Potato Production: Alternative Breeding Strategies
}

\author{
E. T. Lammerts van Bueren • \\ M. Tiemens-Hulscher • P. C. Struik
}

Received: 27 April 2008 /Accepted: 29 April 2008/

Published online: 22 June 2008

(C) EAPR 2008

\begin{abstract}
Average potato yields in Dutch organic farming systems vary from 15 to $29 \mathrm{Mg} / \mathrm{ha}$ and are limited by low input of nitrogen and severe late blight attacks caused by the oomycete Phytophthora infestans. Under Dutch late blight regulations it is mandatory to kill the haulm at $7 \%$ infestation. The late blight attacks have been so early in the organic potato production of the past few years that its acreage is now gradually decreasing whereas consumer demand is increasing. Agronomic control strategies have limited success. First priority lies in breeding for highly resistant varieties to safeguard organic potato production in the Netherlands. Cisgenesis, however, is not an option for the organic sector. Although the product of cisgenesis does not contain genes from non-crossable species it is a result of a genetic engineering process which is excluded from use in organic agriculture. As the principles and standards of organic agriculture are process-based, cisgenesis does not comply with the norms and standards of organic agriculture. The arguments of the organic sector go well beyond the alleged risks of the gene technology and relate to the technology itself. Breeding at DNA-level, instead of at whole-plant level, violates the integrity of life as described in the concept of naturalness. The Dutch organic sector is now aiming at increasing the traditional breeding activities including the participation of farmer-breeders in close cooperation with the formal breeding companies. Additional selection methods need to be developed to include required traits other than late blight resistance, such as nutrient efficiency. Recently
\end{abstract}

E. T. Lammerts van Bueren $(\bowtie) \cdot$ M. Tiemens-Hulscher Louis Bolk Institute, Hoofdstraat 24, 3972 LA Driebergen, The Netherlands

e-mail: e.lammerts@louisbolk.nl

P. C. Struik

Crop and Weed Ecology, Wageningen University, Haarweg 333, 6709 RZ Wageningen,

The Netherlands 
two varieties have been released with high resistance against late blight based on introgressing genes from Solanum bulbocastanum. Organic agriculture can benefit from marker assisted breeding to achieve adequate pyramiding of different, new sources of resistance.

Keywords Cisgenesis - Genetic modification · Organic agriculture ·

Phytophthora infestans $\cdot$ Potato breeding $\cdot$ Solanum tuberosum

\section{Introduction}

Dutch organic farmers are striving for a profitable potato production of $30-40 \mathrm{Mg} / \mathrm{ha}$ in 100-110 days. Under Dutch conditions, the organic potato grower has to deal with two main yield limiting factors: low nutrient availability and late blight infestation.

The mineralization of nutrients from organic fertilizers depends on temperature, moisture and structure of the soil. It is relatively slow in spring and over the growing season it is not sufficient to support crop growth for more than 100 days (Van Delden 2001). The level of available nitrogen in organic production systems in the Netherlands and other European countries lies approx. between 100 and $120 \mathrm{~kg} \mathrm{~N} / \mathrm{ha}$ (Möller 2000; Tamm et al. 2004). The problem of nutrient availability will increase in the future as the organic sector is working towards $100 \%$ input of manure from organic animal husbandry and no derogations will be given for conventionally produced manure.

Average potato yields in Dutch organic farming systems are rather low but also variable ranging from 12 until $35 \mathrm{Mg} / \mathrm{ha}$. The main reason for this year-to-year variation in yield is the variation in timing and severity of late blight attacks, caused by the oomycete Phytophthora infestans. This yield variation casts doubt about the reliability of the organic potato production in the Netherlands. The late blight attacks have been so devastating in the organic potato production of the past few years that its acreage is now gradually decreasing from 1,555 ha in 2002 to 1,217 ha in 2007 (Table 1). The expectations are that 2008 will show a further decline after the disastrous late blight infestations in organic agriculture of 2007. This decline in area cropped to organic potato is in strong contrast with the increase in domestic demand for organic potato by $8.4 \%$ in 2007 . This demand is partly met by imports of early potatoes from Italy, Germany and Israel (Biologica 2008). There is also some export of Dutch organic

Table 1 Area of organic potato production and average yield in the Netherlands (adapted from Biologica 2008)

\begin{tabular}{lrrrrrr}
\hline \multicolumn{7}{l}{ Year } \\
\cline { 2 - 7 } & 2002 & 2003 & 2004 & 2005 & 2006 & 2007 \\
\hline Seed potato (ha) & 363 & 330 & 323 & 307 & 298 & 299 \\
Ware potato (ha) & 1,031 & 993 & 1,031 & 1,045 & 970 & 903 \\
Starch potato (ha) & 161 & 25 & 24 & 13 & 13 & 15 \\
Total area under organic potato (ha) & 1,555 & 1,348 & 1,378 & 1,365 & 1,281 & 1,217 \\
Mean yield (Mg/ha) & 23 & 27 & 29 & 22 & 22 & 15 \\
\hline
\end{tabular}


ware potatoes mainly to Germany. The organic seed crop is exported for a larger portion, as is already signified by the relatively high ratio of seed potato area to total potato area (Table 1), to several countries within Europe (Vergroesen 2004).

Yields are low in years with early attacks because of a national measure which forces every potato grower to kill the vine when $\pm 7 \%$ of the leaf surface is visually affected (HPA 2003) to reduce spread of inoculum to neighbouring fields. This measure makes the growing season relatively short. Möller (2000) proved that up to $60 \%$ infection the yield does not decline as extra growing days in this phase of rapid tuber bulking will increase yield more than the direct tuber yield loss caused by the late blight. However, this is only true when varieties grown have a good tuber resistance.

For the organic ware production in 2007, organically produced seed potatoes of five very early varieties and ten yellow and two red skinned potato varieties of a slightly later maturity type were available (Lammerts van Bueren and Ter Berg 2007). In the dramatic season of 2007 Biogold was the only variety that (although not resistant to late blight) could produce $35 \mathrm{Mg} / \mathrm{ha}$ because of its early tuber bulking. Many other varieties did not yield more than $8-15 \mathrm{Mg} / \mathrm{ha}$. This clearly illustrates the challenges the Dutch organic potato industry is facing.

Many efforts have been put into designing agronomic strategies to increase potato yields by delaying the infection and slowing down the epidemic: developing cultural practices, treating seed tubers to advance the crop and growing early and/or resistant varieties. It is not known whether under Dutch conditions diversification strategies by growing potato in association with another crop in strip cropping, intercropping or mixed cropping are effective enough to slow down the epidemic of late blight (cf. Philips et al. 2005; Pilet et al. 2006). Measures that influence crop structure and microclimate have been shown not to be sufficiently effective and reliable to slow down the initial phase of the epidemic (Bouws and Finckh 2008). Due to the lack of resistant varieties and due to a ban on copper treatments in the Netherlands, the most effective measure is advancing tuber set and tuber bulking (Finckh et al. 2006; Hospers-Brands et al. 2005, 2008; Tiemens-Hulscher et al. 2007).

Taking the limited effects of agronomy strategies into account the only option to safeguard the Dutch organic potato sector is to breed for better adapted and more resistant varieties as selecting resistant cultivars is the only promising and sustainable route for controlling late blight. In an extended trial with 281 cultivars under low-input only 36 cultivars yielded $30 \mathrm{Mg} / \mathrm{ha}$ regardless of late blight infection. However, most of the cultivars did not meet the required minimal levels of dry matter content (under water weight) or cooking and baking qualities (TiemensHulscher et al. 2003).

The resistance level of the varieties currently used in organic agriculture is not sufficient to obtain the desired yield level. There is a need for resistance combined with earliness. Late blight resistance and early maturity type are characters that are difficult to combine as they are genetically and physiologically linked: early varieties and early crops of the same variety are usually much more vulnerable than late varieties or late crops (Visker et al. 2005). As the organic potato sector is so seriously threatened by late blight, an important question is then: can or should organic potato production make use of the novel techniques of genetic modification focusing on incorporating genes that will make the variety resistant to late blight? 


\section{Trans- and Cisgenesis}

Since 1993 the Basic Standards for Organic Production and Processing of the (worldwide) International Federation of Organic Agriculture Movements (IFOAM) include a strict ban on genetically modified organisms (GMOs) (Anonymous 2005). Since 1999, also the EU Regulation for organic agriculture 2092/91/EC prohibits the use of GMOs and the products obtained through the use of GMOs in organic produce (Anonymous 1991). GMOs are therefore legally and morally not acceptable in organic agriculture.

In a position statement the IFOAM argued why such a ban is justified (IFOAM 2002). There are three categories of reasons:

1. Environmental and health risks. In IFOAM's perception such risks are inherently associated with the reductionistic approach of gene technology.

2. Socio-economic aspects. These include the fact that freedom of choice for farmer and consumer is threatened by the risk of contamination of organic produce with genetically modified material when the two types of crops have to co-exist and the fact that intellectual property rights and economic independence are threatened by large-scale use of GMOs.

3. Incompatibility with biological principles of sustainability. This is the most arguable issue in debates between opponents and proponents of the organic position on GMOs and cisgenesis and thus needs to be clarified in this paper.

Verhoog (2007) has described and analysed the different arguments used against GMOs in organic agriculture in great detail.

However, molecular scientists have recently tailored and upgraded gene technology by developing techniques that make these modern plant breeding techniques more efficient and simultaneously more acceptable to the general public, such as cisgenesis (Rommens 2004; Schouten et al. 2006a,b; Rommens et al. 2007). A cisgenesis product is a transformed plant that only contains genes that are innate to the species or to a small group of crossable species. This adds a new dimension to the debate on GMO (Nielsen 2003; COGEM 2006; Lusk and Rozan 2006; Myskja 2006; Russell and Sparrow 2008). When definitions of genetic modification in regulations are merely product-based then for some groups in society there are fewer arguments against cisgenic plants, e.g. because no species barriers are crossed as is the case with transgenesis. However, the EU legislation on GMOs is based on both product and process related arguments.

The organic movement is intrinsically process-based and therefore not only values the product but also the process, including the process of plant breeding. This choice of the organic movement is based on its own ethics and principles (Anonymous 2005). These principles (the principles of ecology, health, care, fairness) were reformulated in 2005 after a worldwide democratic consultation process among the members of IFOAM (Luttikholt 2007).

Product-based assessment of ethical aspects of a technology automatically implies a choice of an ethical approach that only takes the extrinsic consequences of human action into account based on a risk-benefit analysis. Such an ethical approach neglects so-called intrinsic, ethical arguments related to the applied technology (the process) itself. The organic movement is-by its nature-more 
focused on the processed-based, intrinsic argument of 'unnaturalness' against genetic engineering. As products of cisgenesis are a result of a genetic modification process, they can therefore not be accepted by organic agriculture (Lammerts van Bueren et al. 2007).

\section{Risks, Regulations and Legislative Oversight}

The first reason why organic agriculture is against genetic engineering (see previous section) can be described as the 'precautionary principle'. This principle has been formulated in a publication by the Danish Research Centre for Organic Food and Farming (DARCOF; Anonymous 2000) and is consistent with the IFOAM Principle of Care (Anonymous 2005). There are claims from molecular scientists that cisgenesis warrants less strict regulation and legislative oversight than 'conventional' transgenesis, because the ecological risks of the products are allegedly absent or very minor (Schouten et al. 2006a, b).

The second reason why organic agriculture is against genetic engineering has been the subject of hefty political debates and even conflicts between stakeholders resulting in additional rules and regulations on co-existence (Van der Wiel and Lotz 2006), but agreements between organic and conventional sectors in the Netherlands to arrange compensation for possible damage to organic and other non-GMO produce are not yet been reached.

The third reason can be formulated in terms of the concept of naturalness which includes the aspects of non-chemical and ecological approaches, and of respecting integrity of life as described by Verhoog et al. (2003) and Verhoog (2007). So the objections against genetic engineering of organic agriculture go well beyond the risks of the gene technology. They also relate to the technology itself, and the human attitude towards nature it reflects.

The fact that cisgenesis is a genetic modification technique is not disputed. From the process point of view, this breeding technique does not comply with the EU regulations for organic agriculture. Lammerts van Bueren et al. (2003) have argued that plant breeding at DNA-level, instead of at whole-plant level, violates the integrity of life as described in the concept of naturalness. Cisgenesis, like transgenesis, implies that the 'cis' gene(s) are randomly inserted. Therefore there is always an element of unpredictability in the effect of the insertion on the genome and on the concomitant risks. However, some authors (e.g., Schouten et al. 2006a, b) depart from a product point of view and argue that products of cisgenesis are comparable to products of traditional breeding and therefore deserve less strict oversight thus making the use of the technology cheaper and its products more readily available.

Schouten et al. (2006a, b) question whether the product (i.e., the new or modified cultivar) of cisgenesis needs the full risk assessment procedure for admittance. They even suggest that the variety can and should be excluded from the European Directive 2001/18/EC as the process only re-arranges indigenous gene material or uses genes from related species and thus no 'new' genes have been introduced into the new variety or new gene combinations that could not occur by natural processes have been created (Anonymous 2001). What they actually mean is that the products of cisgenesis contain DNA sequences that could have been combined in a new 
variety by traditional breeding. However, they ignore a notion which is crucial for organic breeding: in traditional breeding the 'desired' gene is imbedded in its chromosomal context. For instance, a resistance gene introduced by gene transfer technology will rarely integrate close to its original position (as usually occurs in traditional breeding) and its expression will therefore be influenced by the genomic context (Mes et al. 2000). In the view of organic agriculture, even though no natural species barriers are crossed when inserting a gene from crossable species, isolating a gene from its natural genomic context and its random insertion is still considered as a violation of the genotypic integrity.

\section{How Will Organic Agriculture Cope with Missing this Golden Opportunity?}

GMOs and thus also in future products of cisgenesis containing late blight resistance do not comply with the norms and standards of organic agriculture. The consequence is that the organic sector has to solve the problem of late blight in another way.

Despite the agro-ecological approach in organic agriculture, late blight causes severe losses in potato. To date, very few varieties are available on the market that are sufficiently resistant to late blight, and no effective control treatments are available for organic farmers, apart from copper, which is not allowed in the Netherlands (Speiser et al. 2006). In most years almost every organic potato crop is infected by late blight and yields are on average 30-50\% lower than in conventional agriculture (Tamm et al. 2004). So also organic growers would benefit considerably from new varieties resistant to late blight (Speiser et al. 2006), but not at all costs. The organic potato sector prefers to further explore the potential of traditional breeding yielding a rather constant flow of varieties with a sufficiently high level of resistance.

\section{Alternative: An Organic Breeding Programme}

The organic sector largely depends on the output realized by breeding for conventional agriculture. Although governments aim at reducing the use of agrochemicals, in the conventional potato sector yield still has top priority in breeding programmes as long as disease susceptibility can be neutralized by applying relatively cheap chemical-synthetic crop protection. The results of variety testing for organic potato production have until now shown that too few potato varieties are suitable to be grown in organic farming systems in a profitable way.

Some potato breeding companies make extra efforts to produce varieties especially suitable for organic production and some promising varieties are expected on the short term (see below). Yet, Dutch organic farmers need a constant flow of highly resistant varieties that are adapted to organic growing conditions to cover all market segments and to safeguard the future of the organic potato sector in the Netherlands. Therefore, steps are now undertaken within the Organic Breeding Research Programme of Bioconnect to set up a unique organic breeding programme, with participation of researchers, several breeding companies and organic farmers 
(Bioconnect; http://www.bioconnect.nl). In this organic breeding programme we distinguish roughly three phases:

Phase 1: identifying wild Solanum species with interesting genes and trying to cross these species with diploid or tetraploid forms of the cultivated potato to make these genes available for breeding;

Phase 2: $\quad$ several generations of pre-breeding to develop suitable genitors;

Phase 3: developing of varieties in commercial settings.

The aim is to conduct all steps under organic, low-input growing conditions to cover all traits essential for successful organic potato production. In this new organic breeding programme resistance against late blight will be first priority.

\section{Required Traits}

The organic sector in the Netherlands concluded in 2008 that more emphasis must be put on plant breeding for varieties that are better adapted to organic growing conditions and at the same time meet the requirements of the processors and consumers. To date, the requirements of the consumers of organic potatoes do not differ from those for conventional potatoes. All farmers, traders and consumers like to have potatoes of good quality with a smooth skin, shallow eyes, a beautiful colour and an excellent taste. And all farmers prefer varieties with a high yield and good resistance against several pests and diseases. However, the priority of these latter traits is different for organic and conventional varieties. For organic farmers high yield is not the first priority and the required level lies certainly not as high as in conventional agriculture. Due to high prices for organic potatoes a yield of $30-40 \mathrm{Mg} / \mathrm{ha}$ is sufficient. Top priority is late blight resistance as there are no effective control techniques available.

But late blight resistance is not the only required trait to make a variety suitable for organic growing conditions. The varieties should be nutrient-efficient and early enough to achieve the required yield within 100 days with an organic N-input of 120 $\mathrm{N} \mathrm{kg} /$ ha. Such varieties need to close their crop canopy as soon as possible to allow efficient light interception but also to contribute to weed suppression. Refraining also from all chemical-synthetic inputs, also resistance to other pest and diseases is required. But - again - there are some differences in priority compared to conventional varieties. Due to the wider rotation of 6-7 years cyst nematodes are not a threat to the production, but Rhizoctonia and (silver) scurf are. Due to the lownutrient status also Alternaria is an emerging problem in organic potato production.

Table 2 Potato variety characteristics to adapt to low-input, organic growing conditions

\begin{tabular}{ll}
\hline Root and tuber traits & Vine traits \\
\hline Early tuber set and bulking & Fast soil cover under low nitrogen input \\
High nitrogen efficiency and good recovery & Resistant against late blight and early blight \\
Well functioning root system & \\
Interactive with mycorrhizas & \\
Tolerant to late blight, Rhizoctonia and (silver) scurf & \\
\hline
\end{tabular}


In Table 2 the traits with the highest priority in the crop profile of an organic variety are listed. Such traits are not (yet) of high priority in conventional potato breeding programmes and appropriate selection methods are not yet available.

\section{Genetic Resources}

This organic breeding programme does not have to start from scratch as two new late blight resistant varieties were registered in 2007 and are available for the Dutch organic market: Toluca and Bionica, see http://www.pedigree.com (Van Berloo et al. 2007). The $P$. infestans resistance of these varieties is based on resistance from the wild potato species Solanum bulbocastanum. This resistance has been transferred to the gene pool of cultivated potato through a long breeding process including bridge crossings with four Solanum species (S. acaule, S. bulbocastanum, S. phureja, $S$. tuberosum) and series of backcrossings of which the result is designated as ABPT material. These resistances were discovered and further developed by Hermsen and Ramanna in the 1970s (Hermsen and Ramanna 1973). More varieties are expected to enter the organic market including ABPT resistances (J.P.M. Vergroesen, personal communication).

In the mean time new resistance genes in other wild species (a.o. Solanum demissum, S. berthaultii, S. okadae) are discovered and are being included in prebreeding programmes at Wageningen University, http://www.plantbreeding.wur.nl/ parapluplan/. These genes are also promising for an organic breeding programme.

These new sources of resistances should be integrated in a genetic background that also includes the other required traits for organic potato as much as possible in different combinations.

\section{Small Breeder System}

From the commercial breeding point of view, the organic sector in the Netherlands is (as yet) too small for more intense and specific breeding efforts than currently carried out. A way to make the breeding economically feasible is including participation of farmers in the selection process. Such a participatory approach already exists in the traditional Dutch system of small potato breeders (Van der Zaag 1999). Potato growers (farmer-breeders) cooperate with breeding companies in the selection process. Each year the farmer-breeders receive a number of seedlings (on average 500-1,500) from different crosses from the breeding company and test them for three years on their own farm. The farmer-breeders select, each in their own way and under their own specific growing conditions, the best genotypes according to their own set of priorities. These selected genotypes are returned to the breeding company, which will do the further necessary agronomic tests at several locations. If the genotype will become a registered variety, the farmer and the company will share the royalties according to the contract between farmer and company.

Because many (160) conventional farmer-breeders are included in the Dutch potato breeding industry, the breeding companies can cope with a large number of clones in the selection in a relatively cheap and well organized way and have become very successful (Van Loon 2007). Until now only two organic farmer- 
breeders cooperate in such a way with commercial breeding companies, of which one selects yearly up to 3,000 clones and the other farmer-breeder with some 10 years of selection experience up to 8,000 clones. The latter has been successful with the selection of the variety Bionica which was registered by the associated breeding company in 2007. To increase the number of organic farmer-breeders a course was set up by the Louis Bolk Institute (NL) in 2008 to introduce the basic principles of potato breeding and selection to a first group of 16 interested farmers. The farmers will be supervised by an experienced potato breeder. Many companies have shown interest in this training course also for their conventional farmer-breeders in future, as no such course existed until now.

\section{Discussion and Conclusions}

With the increased attention for GMO approaches where the targeted gene can directly be inserted into the cultivated varieties making the middle phase of prebreeding (backcrossing) redundant, less financial support will go to the classical pre-breeding phase which will be a threat to the broadening of the genetic base of potato breeding programmes.

As the organic sector refrains from a GMO based solution to obtain late blight resistance, and as yields have been too low in the recent years to make organic potato production economically feasible, the Dutch organic sector is now aiming at increasing the traditional breeding activities towards appropriate varieties that comply with the ecological and ethical principles of the organic agriculture. Through its combination of traditional methods and new ecological and ethical principles these activities are innovative.

As Wageningen University (NL) has conducted a (small) pre-breeding programme in the past years already genetic resources containing promising new resistance genes are available to include in this joint organic breeding programme. However, as the Dutch government has withdrawn more and more its support for pre-breeding activities, only a few, large breeding companies can afford such a longterm pre-breeding programme to develop a broad spectrum of genitors. More financial support is necessary to increase the pre-breeding activities not only to include late blight resistance genes but also to include other important traits. These other traits include at least Rhizoctonia resistance and nutrient use efficiency.

Such an organic breeding programme can only be successful and economically feasible when the number of organic farmer-breeders will increase in the near future and together evaluate at least 20,000 clones per year. Potato breeding is a long-term activity and is a continuous search for new resistance sources, pre-breeding and commercial breeding. These three phases need to run parallel to serve the organic sector with appropriate varieties for the short term, mid-term and long-term future. The release of two new resistant varieties shows that with efforts of more farmers obtaining more varieties in the future is achievable.

The conventional breeding programmes can benefit from such a broad prebreeding program aiming at varieties adapted to low-input farming conditions as a necessary element towards sustainable agriculture. It is one of the arguments of the six breeding companies that have expressed their commitment to cooperate. 
The genes that will be used both in the proposed cisgenic approach and the organic breeding programme are race-specific $R$-genes. This kind of resistance is assumed to be not durable, especially when sexual reproduction of the pathogen is occurring with both mating types of the oomycete being present. Therefore both approaches would require constant addition of new $R$-genes, and pyramiding of these genes in many different combinations.

Marker assisted breeding using freely accessible markers will be a necessary instrument to achieve adequate pyramiding.

\section{References}

Anonymous (1991) (Amended 1999) Council Regulation (EEC) No 2092/91 of 24 June 1991 on organic production of agricultural products and indications referring thereto on agricultural products and foodstuffs, including all amendments. Official Journal No L 198, 22.7.1991. European Economic Community, Brussels

Anonymous (2000) Principles of organic farming. DARCOF, Foulum

Anonymous (2001) European Directive 2001/18/EC. Official Journal European Commission L 106. European Community, Brussels

Anonymous (2005) The IFOAM norms for organic production and processing, version 2005. IFOAM, Bonn

Biologica (2008) Bio-Monitor jaarrapporten 2002-7/Biologica. Available at http://www.biologica.nl/bio-monitor/. Accessed 28 Apr 2008

Bouws H, Finckh MR (2008) Effects of strip-intercropping of potatoes with non-hosts on late blight severity and tuber yield in organic production. Plant Pathol (in press)

COGEM (2006) Ethical and societal aspects of cisgenesis. Monitoring report 060202-02. The Netherlands Commission on Genetic Modification (COGEM), The Netherlands. Available at http://www.cogem.net. Accessed 28 April 2008

Finckh MR, Schulte-Geldermann E, Bruns C (2006) Challenges to organic potato farming: disease and nutrient management. Potato Res 49:27-42

Hermsen JGTH, Ramanna MS (1973) Double-bridge hybrids of Solanum bulbocastanum and cultivars of Solanum tuberosum. Euphytica 22:457-466

Hoofdproductschap Akkerbouw, sector Aardappelen (HPA) (2003) Ontheffingenbeleid bestrijding Phytophthora infestans 2003. 23 januari 2003, N021361a.BK.

Hospers-Brands AJTM, Struik PC, Tiemens-Hulscher M, van der Putten PEL, Jansen E (2005) Effects of physiological age of seed tubers on tuber yield and the susceptibility of the potato crop to late blight (Phytophthora infestans) in organic agriculture. Proceedings of the 16th triennial conference of the EAPR, 17-22 July, Bilbao, Spain, pp 432-436

Hospers-Brands M, Timmermans B, van der Putten P, Struik P, Tiemens-Hulscher M, Lammerts van Bueren E (2008) Late blight in organic potato growing managing resistance and early tuber growth. Proceedings ISOFAR world congress (in press)

IFOAM World Board (2002) Position on genetic engineering and genetically modified organisms. PO1 IFOAM, Bonn

Lammerts van Bueren ET, Ter Berg C (2007) Biologisch uitgangsmateriaal voor 2008: Eindrapportage met het advies van de expertgroepen voor het ministerie van LNV. Louis Bolk Instituut, Driebergen

Lammerts van Bueren ET, Struik PC, Tiemens-Hulscher M, Jacobsen E (2003) The concepts of intrinsic value and integrity of plants in organic plant breeding and propagation. Crop Sci 43:1922-1929

Lammerts van Bueren ET, Verhoog H, Tiemens-Hulscher M, Struik PC, Haring MA (2007) Organic agriculture requires process rather than product evaluation of novel breeding techniques. NJASWageningen J Life Sci 54(4):401-412

Lusk JL, Rozan A (2006) Consumer acceptance of ingenic foods. Biotechnol J 1:1-2

Luttikholt LWM (2007) Principles of organic agriculture as formulated by the International Federation of Organic Agriculture Movements. NJAS-Wageningen J Life Sci 54:347-360

Mes JJ, van Doorn AA, Wijbrandi J, Simons G, Cornelissen BJ, Haring MA (2000) Expression of the Fusarium resistance gene I-2 co-localizes with the site of fungal containment. Plant J 23:183-193 
Möller K (2000) Einflu $\beta$ und Wechselwirkung von Krautfäulebefall (Phytophthora infestans (Mont.) de Bary) und Stickstoffernärung auf Knollenwachstum und Ertrag von Kartoffeln (Solanum tuberosum) im Ökologischen Landbau. Technical University of Munich, Munich

Myskja BK (2006) The moral difference between intragenic and transgenic modification of plants. J Agric Environ Ethics 19:225-238

Nielsen KM (2003) Transgenic organisms - time for conceptual diversification? Nat Biotechnol 21:227-228

Phillips SL, Shaw MW, Wolfe MS (2005) The effect of potato variety mixtures on epidemics of late blight in relation to plot size and level of resistance. Ann Appl Biol 147:245-252

Pilet F, Chacón G, Forbes GA, Andrivon D (2006) Protection of susceptible potato cultivars against late blight in mixtures increases with decreasing disease pressure. Phytopathology 96:777-783

Rommens CM (2004) All-native DNA transformation: a new approach to plant genetic engineering. Trends Plant Sci 9(9):457-464

Rommens CM, Haring MA, Swords K, Davies HV, Belknap WR (2007) The intragenic approach as a new extension to traditional plant breeding. Trends Plant Sci 12:397-403

Russell AW, Sparrow R (2008) The case for regulating intragenic GMOs. J Agric Environ Ethics 21:153-181

Schouten HJ, Krens FA, Jacobsen E (2006a) Do cisgenic plants warrant less stringent oversight? Nat Biotechnol 24:753

Schouten HJ, Krens FA, Jacobsen E (2006b) Cisgenic plants are similar to traditionally bred plants. EMBO Rep 7:1-4

Speiser B, Tamm L, Amsler T, Lambion J, Bertrand C, Hermansen CA, Ruissen MA, Haaland P, Zarb J, Santos J, Shotton P, Wilcockson S, Juntharathep P, Ghorbani R, Leifert C (2006) Improvement of late blight management in organic potato production systems in Europe: field tests with more resistant potato varieties and copper based fungicides. Biol Agric Hortic 23:393-412

Tamm L, Smit AB, Hospers M, Janssens SRM, Buurma JS, Molgaard JP, Laerke PE, Hansen HH, Hermans A, Bodker L, Bertrand C, Lambion J, Finckh MR, van Lammerts CE, Ruissen T, Nielsen BJ, Solberg S, Speiser B, Wolfe MS, Phillips S, Wilcoxon S, Leifert C (2004) Assessment of the socio-economic impact of late blight and state-of-the-art management in European organic potato production systems. FiBL Report, Research Institute of Organic Agriculture FiBL, Frick, Switzerland. Available at http://www.orgprints.org/2936

Tiemens-Hulscher M, Colon LT, Flier WG, Kessel GJT, Budding DJ, ter Berg C, Burgt GJ van der, Hospers M, Lammerts van Bueren ET (2003) Naar beheersingsstrategieën voor Phytophthora infestans in de biologische aardappelteelt. Louis Bolk Instituut, Driebergen; Plant Research International, Wageningen

Tiemens-Hulscher M, Lammerts van Bueren ER, Hospers-Brands AJTM, Timmermans BGM, van der Putten PEL, Struik PC (2007) Blijft biologische aardappelteelt in Nederland mogelijk? Gewasbescherming 35:246-250

Van Berloo R, Hutten RCB, van Eck HJ, Visser RGF (2007) An online potato pedigree database resource. Potato Res 50:45-57

Van Delden A (2001) Yield and growth of potato and wheat under organic N-management. Agron J 93:1370-1385

Van de Wiel CCM, Lotz LAP (2006) Outcrossing and coexistence of genetically modified with (genetically) unmodified crops: a case study of the situation in the Netherlands. NJAS-Wageningen J Life Sci 54:17-35

Van der Zaag D (1999) Die gewone aardappel—geschiedenis van de aardappel en de aardappelteelt in Nederland. B. van der Zaag, Wageningen

Van Loon JP (2007) Small potato breeders in The Netherlands, history and actual situation. In: Osman AM, Müller K-J, Wilbois K-P (eds) Different models to finance plant breeding. Proceedings of the ECO-PB International Workshop on 27 February 2007 in Frankfurt, Germany. European Consortium for Organic Plant Breeding, Driebergen/Frankfurt, pp 17-19

Vergroesen JPM (2004) Growing organic seed potatoes in the Netherlands. In: Lammerts van Bueren ET, Ranganathan R, Sorensen N (eds) Proceedings of the 1st world IFOAM/ISF/FAO conference on organic seed - challenges and opportunities for organic agriculture and the seed industry, Rome, Italy, 5-7 July, IFOAM, Bonn, pp 98

Verhoog H (2007) Organic agriculture versus genetic engineering. NJAS-Wageningen J Life Sci 54:387400

Verhoog H, Matze M, Lammerts van Bueren E, Baars T (2003) The role of the concept of the natural (naturalness) in organic farming. J Agric Environ Ethics 16:29-49

Visker MHPW, Heilersig HJB, Kodde LP, van der Weg WE, Voorrips RE, Struik PC, Colon LT (2005) Genetic linkage of QTLs for late blight resistance and foliage maturity type in six related potato progenies. Euphytica 143:189-199 